(C) 1983 ISIJ

\title{
鉄の粒界に偏析したリンの化学結合状態
}

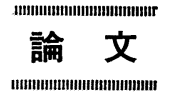

\author{
安彦 兼次*·鈴木 茂*·木村宏*
}

\section{Chemical State of Phosphorus Segregated at Grain Boundaries of Iron}

\author{
Kenji Aвrкo, Shigeru Suzukr, and Hiroshi Kimura
}

\begin{abstract}
Synopsis :
Determination of the chemical state of phosphorus segregated at grain boundaries of iron is important to discuss mechanisms of the grain boundary decohesion by phosphorus. $\mathrm{X}$-ray photoelectron spectroscopy (XPS) analysis and the scanning Auger electron spectroscopy (AES) analysis were performed to determine the chemical state of segregated phosphorus.

Specimens of iron containing various amount of phosphorus $(0.05$ to $15.6 \mathrm{wt} \%)$ were fractured under a vacuum better than $6 \times 10^{-11}$ Torr. The clean ultra-high vacuum allows a prolonged XPS analysis $(\sim 10 \mathrm{~h})$ which is necessary for a small amount of phosphorus segregated at grain boundaries. The spectra were compared with those from an $\mathrm{Fe}_{3} \mathrm{P}$ specimen, and the chemical state of the segregated phosphorus was determined to be the same as phosphorus in $\mathrm{Fe}_{3} \mathrm{P}$. This result supports the grain boundary decohesion mechanism proposed by Losch, who considers the segregated phosphorus atoms to form a strong binding with surrounding iron atoms and the iron-iron binding neighboring the phosphorus to be weaken.

The shape of AES of phosphorus in solid solution varies with the concentration of phosphorus, but that of phosphorus at grain boundaries is independent of the phosphorus concentration and same as that of phosphorus in $\mathrm{Fe}_{3} \mathrm{P}$. Importance of the variation of the shape in the AES quantitative analysis of segregated phosphorus is discussed.
\end{abstract}

\section{1. 緒言}

$\mathrm{P}$ の粒界偏析が鉄鋼の粒界脆性の原因となることは, $\mathrm{Ni}-\mathrm{Cr}$ 鋼， $\mathrm{Cr}-\mathrm{Mo}$ 鋼などの焼もどし脆性にその例を見 るように，よく知られた事実である。 また，電解鉄程度 の純鉄でも炭素量の少ない時はPによる粒界脆化が括こ る1)。乙かし，P に代表されるような不純物の偏析によ る粒界結合力の低下の機構については, 原子論的, 電子 論的な試論がいくつか提案されているが,いまだ理論的, 実験的に確立された考方方はない、 $\mathrm{SEAH}^{2}$ は, 粒界に偏 析した不純物は粒内に固溶しているときと同じ結合様式 で $\mathrm{Fe}$ 原子と結びついて拈り, また破壊は $\mathrm{Fe}$ 原子と不 純物原子の間の結合がきれることでおこると仮定して, 種々の不純物による粒界脆化の程度を議論している. そ の議論に打いては，粒界偏析した不純物に対して稀薄正 則溶液の近似を用いるなど現実的でない点があり，かな らずしも事実をよく説明しているとは言兄ない3).一方， $\operatorname{LoscH}^{4)}$ は, 粒界偏析した不純物原子は周囲の $\mathrm{Fe}$ 原子 と共有結合的な強い結合をし，そのため不純物原子にと なり合つている $\mathrm{Fe}$ 原子とさらにそのまわりの $\mathrm{Fe}$ 原子と の間の結合が弱められていると考えている.この場合，
破壊は不純物原子と $\mathrm{Fe}$ 原子との間ではなく, 不純物原 子のまわりの $\mathrm{Fe}$ 原子同志の結合をきつて伝播すること となる. 同様の考方方は石田ら5)，MESSMER ら6)によつ ても提唱されて招り，これに対する実験的な支持は，鉄 の粒界に偏析した Sn のメスパウワー効果の測定 ${ }^{5)}$, = ッケルの表面に偏析した $\mathrm{S}$ の電子状態の研究7)によつて あたえられているが，鉄鋼中でもつとも問題とされてい る $\mathrm{P} か ゙$ 粒界偏析した時の化学結合状態については，いま だ実験結果は報告されていない。

原子の化学結合状態の研究に適した手段としてX線光 電子分光法（XPS）があるが，これは感度が低いため， 粒界偏析のように測定にかかる不純物量が少ない（粒界 面での不純物濃度はかなり高いが, 偏析層の厚さが数原 子層ときわめて薄いため, 分析される不純物量は少ない) 場合には，長時間にわたつてデータを集積しなければな らない.ところが, 分析器の真空度が十分でないと，真 空槽中で試料を破断して粒界面を露出させた時, 真空槽 中の残留ガスで短時間のうちに污染され，長時間にわた つて清浄な破面で分析することが難しい，したがつて， XPS による偏析不純物の状態分析は従来全く行われて いなかつた. また，表面（粒界）分析手段としてはオー 
ジェ電子分光法 (AES) があり,これは感度が高く測定 は短時間ですむが，オージェ電子ェネルギー分布は原子 の化学結合状態に敏感でないとされて和り, このために AES を状態分析に積極的に 利用しょうといら試みはほ とんどなされていないわれわれは，AES 拈よび XPS を, 同一分析器中で, 残留ガスによる破面污染のほとん ぞ扣こらない超高真空中で行うことに成功し，鉄の粒界 に偏析した $\mathrm{P}$ の化学結合状態についていくつかの情報を 得ることができたので報告する.

\section{2. 実 験 方 法}

\section{$2 \cdot 1$ 試 料}

電解鉄（マイロン）を高周波真空溶解し，白鉄を添加 して脱酸したのち， $\mathrm{Fe}-25 \% \mathrm{P}$ 母合金を添加して金型に 鋳造し $\mathrm{Fe}-\mathrm{P}$ 合金インゴットを作つた.これに， 1000 ${ }^{\circ} \mathrm{C}$ から $800^{\circ} \mathrm{C}$ の間で熱間加工を加えて, 直径 $4 \mathrm{~mm}$ の 丸棒としたのち, 機械加工によつて直径 $3.6 \mathrm{~mm}$, 長さ

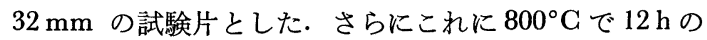
湿水素処理, $800^{\circ} \mathrm{C}$ で $12 \mathrm{~h}$ の乾水素処理を行つて, $\mathrm{C}$ 量を 10 ないし $20 \mathrm{wt}$ ppm とした. これらの試験片は すべて $900^{\circ} \mathrm{C}$ に $30 \mathrm{~min}$ 保持してから油焼入された. したがつて, 組織は $\alpha$ 相単相である. 光学顕微鏡掞よび 50000 倍程度の透過電子顕徽鏡観察に上れば, 粒内, 粒 界のいずれにも炭化物もしくはリン化物の析出は見られ なかつた、な扮，溶製した合金の組成は，Pを 0.05 か ら $2.8 \mathrm{wt} \%$ まで 7 種類とつてあり， $\mathrm{Si}, \mathrm{Mn}, \mathrm{Al}, \mathrm{S}$ はそれぞれ，0.005，0.005，0.003，0.003 wt \% の程 度であり, $\mathrm{O}$ は $50 \mathrm{wt} \mathrm{ppm}$ 以下である.

試験片にはVノッチをつけ，超高真空の分析器中で約 $170 \mathrm{~K}$ 以下に冷却してからノッチ部で破断し，そのまま 走査オージェ電子分光 (SAM) または XPS 分析を行つ た. XPS 用試験片は，Vノッチをつけたのち, 表面全 体に $10 \mu$ 程度の厚さに Au を蒸着した.これには $2 つ$ の目的がある. 第1に，XPS 法に打いてはX線ビーム の直径が約 $5 \mathrm{~mm}$ と太いため, 試験片の破面のみならず ノッチ部怙よび側面まで分析領域に入つてしまう，Au を蒸着することでこれらの領域からの不必要かつ有害な 情報を遮断できる. 第 2 に，この $\mathrm{Au}$ の $4 \mathrm{f}_{7 / 2}$ の結合エ ネルギーを光電子ェネルギー測定の基準として用いるこ とでェネルギー分析の精度を向上させ得る.

\subsection{SAM および XPS 分析}

SAM は PHI 社 590 型, XPS は同社 550 型を用 い, 次の条件で測定した.

SAM 分析 :

試験片破断時の真空度 $\quad 4 \sim 6 \times 10^{-11}$ Torr

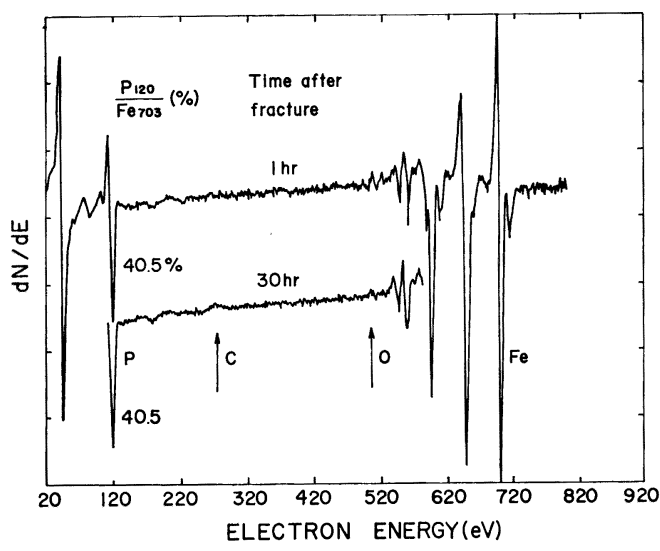

Fig. 1. AES from a grain boundary fracture surface taken $\mathrm{lh}$ and $30 \mathrm{~h}$ after breaking the specimen under ultra high vacuum better than $8 \times 10^{-11}$ Torr.

SAM 分析中の真空度 $4 \sim 8 \times 10^{-11}$ Torr 電子線加速電圧 $3 \mathrm{kV}$

モジュレーション $3 \mathrm{eV}$ (または $1 \mathrm{eV})$

試料電流 $100 \mathrm{nA}$

電子線径 約 $5 \mu$

$\mathrm{SAM}$ 分析時間破断後 $1 \mathrm{~h}$ 以内, 残留ガス による破面の污染の有無を調べる目的の場合は破 断後 $48 \mathrm{~h}$ まで分析した.

ここで試料電流に注意されたい。これは通常マイクロ ビームオージェ電子分光装置で用いられているものの約 $1 / 100$ であり, 試料電流密度は $5 \mathrm{~mA} / \mathrm{mm}^{2}$ である.こ のため, 時々心配されるような電子線照射による分析場 所での局部的温度上昇は問題にならない。

XPS 分析 :

試験片破断時の真空度 $4 \sim 6 \times 10^{-11}$ Torr

XPS 分析中の真空度 $<2 \times 10^{-10}$ Torr ( $\mathrm{X}$ 線源の 発熱量が大さいので真空度が低下する)

X線源拈よび加速電圧 $\mathrm{MgK}_{\alpha}, 10 \mathrm{kV}$

$\begin{array}{ll}\text { エミッション } & 40 \mathrm{~mA} \\ \text { パスェネルギー } & 50 \mathrm{eV}\end{array}$

XPS 分析時間破断後 $10 \mathrm{~h}$ にわたつてデ 一タを集積

\section{3. 実験結果および考察}

\section{$3 \cdot 1$ 測定中の残留ガスによる破面の污染}

Fig. 1 は $\mathrm{Fe}-1.0 \% \mathrm{P}$ 合金の破面における粒界部分に ついてのオージェスペクトルである. 残留ガスによる污 染は $\mathrm{C}, \mathrm{O}$ のピークの出現となつて検出されるが，こ れは破断後 $30 \mathrm{~h}$ でようやく検出される程度である. ま 

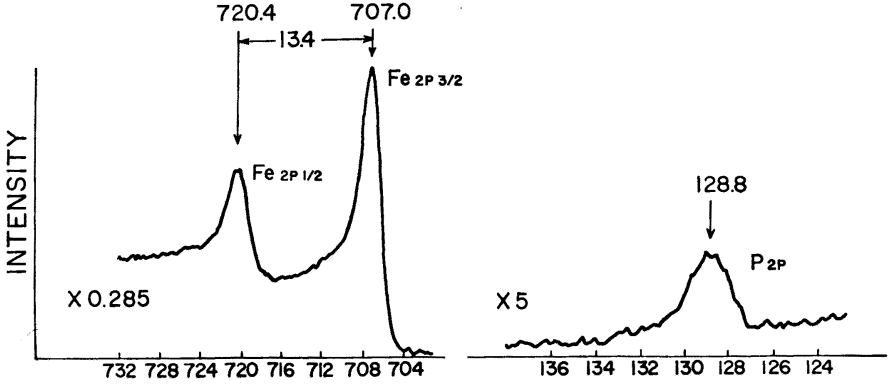

BINDING ENERGY (eV)

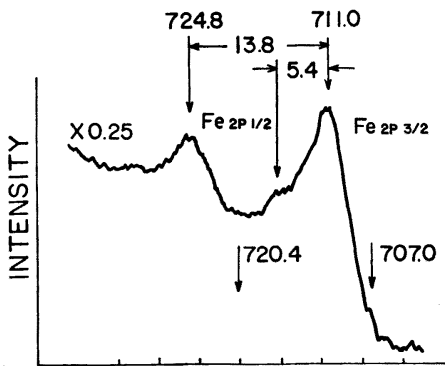

732728724720716712708704

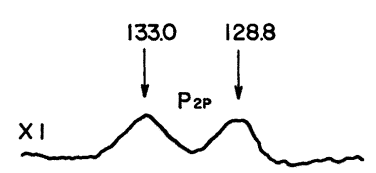

BINDING ENERGY (eV)

Fig. 2. XPS for iron and phosphorus from the fracture surface of an $\mathrm{Fe}-1.0$ $\% \mathrm{P}$ alloy specimen. The specimen was fractured in the analyzing chamber.
た, $\mathrm{P}(120 \mathrm{eV})$ と $\mathrm{Fe}(703 \mathrm{eV})$ のピーク高さ比は 40.5 \%で，これも $30 \mathrm{~h}$ で変化なかつた. 図には示してない が, 本実験ではへき開面は粒界面よりも污染されやすく， $10 \mathrm{~h}$ でわずかながら C, O のピークが認められた. ま た，へき開面では污染の進行にともない $\mathrm{P}_{120} / \mathrm{Fe}_{\mathbf{7 0 3}}$ は若 干減少する、これは，へき開面では分析にかかる $\mathrm{P}$ 量が 少ない上に, Pのオージェ電子の方が Fe のオージェ電 子よりも低エネルギーのため脱出深さが浅く, 表面に吸 着した $\mathrm{G} ， \mathrm{O}$ によつてオージェ電子が遮へいされる割

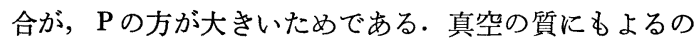
で，いちがいには言えないが，8×10-11Torrよりよい真 空中であれば，偏析した $\mathrm{G}, \mathrm{O}$ を吸着した $\mathrm{C}, \mathrm{O}$ と混同 することなく，必要に応じて十分の時間をかけて，AES 分析を行うことができるといえよう.

XPS 分析では, $\mathrm{MgK}_{\alpha} \mathrm{X}$ 線源の温度があがるので測 定中の真空度が低下する．本実験では微量の P の分析を 行うため $10 \mathrm{~h}$ にわたつて測定を行い $\mathrm{S} / \mathrm{N}$ 比を向上させ た.この時の真空度は $2 \sim 3 \times 10^{-10} \mathrm{Torr}$ であつた. 测定 のはじめと終わりで $\mathrm{SAM}$ 分析を行つたところ, 残留ガ スによる污染 $(\mathrm{C} ， \mathrm{O})$ が認められた. この污染によつて

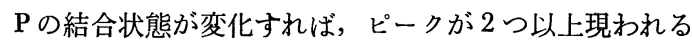
か, スペクトルが拡がるはずであるが，得られたピーク は1つでその拡がりは他の場合に比べてとくに大きいと は言えない程度であつた(次節)．したがつて，わずかな
$\mathrm{C} ， \mathrm{O}$ の污染によつては粒界偏析した $\mathrm{P}$ の化学結合状態 は変化しないと考えられる。

\section{2 粒界偏析した P の XPS 分析}

Fig. 2 は $5 \times 10^{-11}$ Torr の真空中で破断し, 常に $3 \times$ 10-10Torr よりもよい真空中で行つた $\mathrm{Fe}-1.0 \% \mathrm{P}$ 合金 の XPS 分析の結果である. 破面は 100\% 粒界破面に 近く， $\mathbf{P}$ に関して得られた情報は粒界偏析した $\mathbf{P}$ につ いてのものである. $\mathrm{Fe} 2 \mathrm{p}_{1 / 2}, \mathrm{Fe} 2 \mathrm{p}_{3 / 2}$ と $\mathrm{P} 2 \mathrm{p}$ のスペク トルだけを示してある. $\mathrm{Fe} 2 \mathrm{p}_{1 / 2}, \mathrm{Fe} 2 \mathrm{p}_{3 / 2}$ のスペクトル は，それぞれ $720.4 \mathrm{eV}, 707.0 \mathrm{eV}$ に位置し，これは金 属状態の $\mathrm{Fe}$ のスペクトルである8)， P のスペクトルは $128.8 \mathrm{eV}$ に位置している. これらの值は $\mathrm{Au}_{4} \mathrm{f}_{7 / 2}$ のピ 一クを $83.3 \mathrm{eV}$ として求めたものである. $\mathrm{P}$ のピーク 位置は単体の $\mathrm{P} の \mathrm{P} 2 \mathrm{p}$ ピークの $129.7 \mathrm{eV} 9), \mathrm{P}_{2} \mathrm{O}_{5}$ 中 の $\mathrm{P} 2 \mathrm{p}$ ピークの $\left.135.0 \mathrm{eV}^{10}\right)$ のいずれよりもたしかに 小さいところにある. この $\mathrm{P}$ の位置に相当するリンの化 合物はまだ報告されていないすすなわち，粒界偏析した Pは XPS 的には未知の化学結合状態にある.しかし， 特そらく $\mathrm{Fe}_{3} \mathrm{P}$ といつた鉄との化合物中のリンの状態に 近いと推察されるので, $\mathrm{Fe}_{3} \mathrm{P}$ との比較を行つた. $\mathrm{Fe}_{3} \mathrm{P}$ 中の P2p のスペクトルはまだ測定されていないので, $\mathrm{Fe}_{3} \mathrm{P}$ についての分析を行つた. 試料表面は空気中の $\mathrm{O}$, $\mathrm{H}_{2} \mathrm{O}, \mathrm{CO}_{2}$ などで污染されているが，そのままの状態 での分析結果を Fig. 3 に示す. Fe のピークは, この 


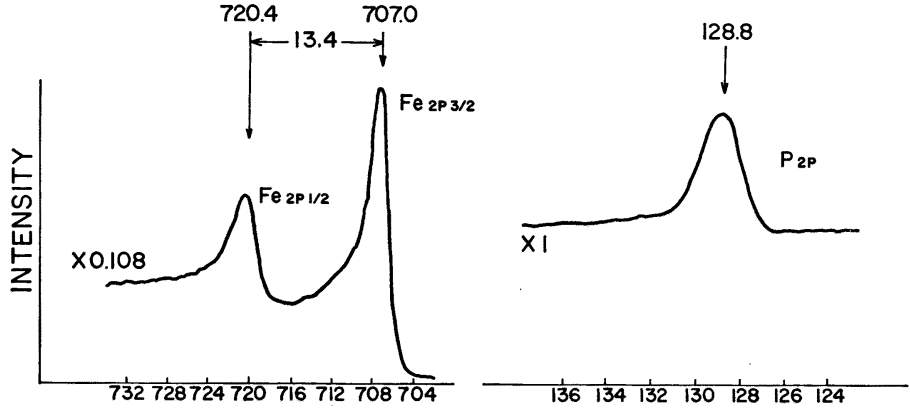

BINDING ENERGY ( eV)
Fig. 4, XPS (for Fe and P) from the same specimen as in Fig. 3, but cleaned by Ar ion sputtering.
$\mathrm{Fe}$ がウスタイトのような $\mathrm{Fe}(\mathrm{II})$ の状態にあることを

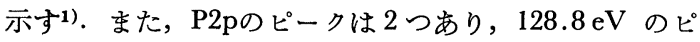
一クは上述のと拈り未知のものであるが， $133.0 \mathrm{eV}$ の ピークは, 現在までに報告されている結果と比べると, たとえば $\left(\mathrm{C}_{8} \mathrm{H}_{17}\right)_{3} \mathrm{PO}$ 中の $\mathrm{P} 2 \mathrm{p}$ ピーク $132.6 \mathrm{eV}$ にき わめて近いこれらの結果は, 空気中に長時間さらして いちじるしく活染された表面では $\mathrm{Fe}_{3} \mathrm{P}$ 中の $\mathrm{P} 2 \mathrm{p}$ スペ クトルを正確に求められないことを示している. そこ

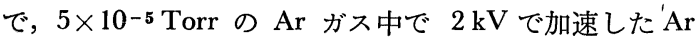
イオン・スパッタリングを行つたのち, XPS 分析を行 つた. 結果 をFig. 4 に示す. $\mathrm{Fe} 2 \mathrm{p}_{1 / 2}, \mathrm{Fe} 2 \mathrm{p}_{\mathbf{3} / 2}$ のピー クは金属状の $\mathrm{Fe}$ のピークと同じ位置になり, $\mathrm{P} 2 \mathrm{p} の$ $133.0 \mathrm{eV}$ のピークは消え, $128.8 \mathrm{eV}$ のピークだけとな つた. すなわち, $128.8 \mathrm{eV}$ のピークは $\mathrm{Fe}_{3} \mathrm{P}$ の $\mathrm{P} 2 \mathrm{p}$ の ピークであると結論できる†. したがつて，粒界偏析し た Pの化学結合状態は $\mathrm{Fe}_{3} \mathrm{P}$ 中の $\mathrm{P}$ の結合状態と同じも のであることが結論される.なお， $\mathrm{Fe}-0.1 \% \mathrm{P} ，$ および $\mathrm{Fe}-0.05 \% \mathrm{P}$ 合金についても, 粒界偏析したPについて 全く同じ結果が得られている.

粒界に偏析した $\mathrm{P}$ は $\mathrm{Fe}_{3} \mathrm{P}$ 中の $\mathrm{P}$ と同じ化学結合状態 にあることがわかつたが，このことは，Pが粒界に $\mathrm{Fe}_{3} \mathrm{P}$ として析出していることを意味するものではない. 透過 電顕法では粒界に析出物の存在は認められなかつたし, Ar イオン・スパッタリング後の AES 分析では, P の偏 析は粒界面から数原子層の間に限定されていることが示 された. かりに $\mathrm{Fe}_{3} \mathrm{P}$ 結晶と同じ結晶構造を考えるとす れば，きわめて薄い 2 次元的な形といらべきである．ま た，粒界偏析した $\mathrm{P}$ 濃度の高い領域の厚さを推定する方 法を提案した論文に拈いては12), 表現の便宜上, 粒界面 およびその直下の原子層に括いて， $\mathrm{P}$ が $\mathrm{Fe}_{3} \mathrm{P}$ の組成で

† 用いた $\mathrm{Fe}_{3} \mathrm{P}$ 試料は柱状晶であり, 柱状晶間に若干の不紝物, 特に O，の存在するてとが考えられる. 本実験での結果にはそれら不純 物の影響が全くないとは言いきれないので，とのピークは純粋な $\mathrm{Fe}_{3} \mathrm{P}$ のものとは断定できないが，不純物量は少ないので $\mathrm{Fe}_{3} \mathrm{P}$ の ものとしてよい.
一様に分布しているとして偏析層の厚さを算出したが， $\mathrm{P}$ の分布は一様とは限らない. 粒界面上で, P濃度の高 い領域が島状に分散している可能性も考兄られる.いず れにせよ, 本実験の結果は偏析したPの化学結合状態に ついての情報を与えるのみであつて，P の結晶学的存在 形態や分布についての情報を与えるものではないことを 注意して执きたい。

以上の結果は， $\mathrm{P}$ の偏析による $\mathrm{Fe}$ の粒界結合力の低 下については, LoscH らのモデルを支持している. SEAH のモデルは，すでに述べたようにその仮定や近似に無理 があるように思われるが，本実験の結果たけけで SEAH の モデルを積極的に否定することはできない. SEAH のモ デルのひとつの仮定となつている固溶した $\mathrm{P}$ 原子のその まわりの $\mathrm{Fe}$ 原子との結合状態が偏析した場合も変わら ないといら点について, 本研究の XPS 分析では検討す ることができなかつた.すなわち，この点の検証には $\mathrm{Fe}$ 中に固溶したPについて XPS 分析を行う必要があ るが，そのためにへき開面で XPS 測定を行おうとする と，測定にかかるPの量が非常に少なくて測定は事実上 不可能である. したがつて，固溶した $\mathrm{P}$ と偏析した $\mathrm{P} に$ ついて XPS 分析で結合状態を比較することは現在は不 可能である.

\section{$3.3 \mathbf{P}$} 性

オージェ電子スペクトルの形状およびピーク位置など は，対象となつている原子の結合状態にはほとんど影響 されないとされているが，スペクトルの微分曲線の形が 結合状態に依存するといら報告もある13). AES は XPS に比べるとはるかに感度がよいので,へき開面について， すなわち固溶状態の P について分析することが可能であ る.とこで，へき開面と粒界面とでPのオージェスペク トルの形（微分形）がどう変わるかを調べて, 結合状態 についての情報が得られるか否かを検討した。

Fig. 5 は, 0.05, 0.11, 0.53, 1.0, 1.7, 2.0, 2.8, 


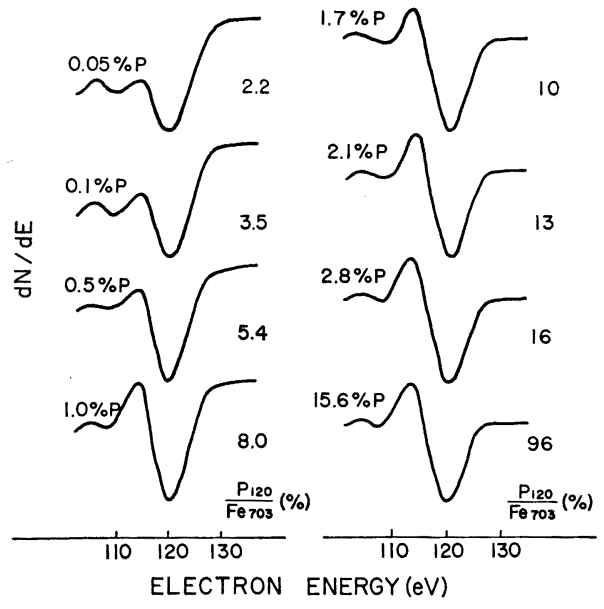

Fig. 5. AES of phosphorus taken from the cleavage fracture surface of $\mathrm{Fe}-\mathrm{P}$ alloys. The $\mathrm{P}$ concentration is shown in the figure. The number on the right of each spectrum is the actual peak-to-peak height ratio $\left(\mathrm{P}_{\mathbf{1 2 0}} / \mathrm{P}_{\mathbf{7 0 3}}\right)$.

および $15.6 \% \%^{\dagger 2}$ の P を含む試料のへき開面からのP スペクトルを示す．P濃度に応じて縦軸のスケールを 変えてピーク高さを揃えてある．P濃度にしたがつてス ペクトルの形が変化している. Fig. 6 は同じ試料の粒界 破面からのスペクトルである.やはり縦軸のスケールを 変えている. Fig. 5 に示した $\mathrm{Fe}_{3} \mathrm{P}$ に対するものも含め て，曲線はたがいにぴつたり重ね合せることができる. すなわち, 粒界偏析した $\mathrm{P}$ も $\mathrm{Fe}_{3} \mathrm{P}$ 中の $\mathrm{P}$ も同じ形のス ペクトルを示す.（今後縦軸のスケールを変えることで 曲線を重ねることができる場合，スペクトルの形が同じ

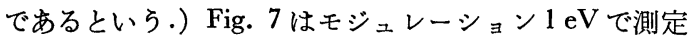
した $\mathrm{Fe}-1 \% \mathrm{P}$ 合金の粒界破面からのPのスペクトルで ある. その形は時間がたつても全く変化しない.もしも オージェ電子スペクトルの形がその元素の化学結合状態 を反映するものであれば, Fig. 6 の結果は, 粒界偏析した $\mathrm{P}$ と $\mathrm{Fe}_{3} \mathrm{P}$ 中の $\mathrm{P}$ とは同じ結合状態であるという前節の 結論と一致し, Fig. 5 の結果と比較すれば, 固溶した $\mathrm{P}$ の結合状態は $\mathrm{P}$ 濃度に依存し, 偏析した $\mathrm{P}$ の状態とは異 なると言えよう、しかし，現在ではここまで結論するこ とはもずかしい，オージェ電子スペクトルの 形の変化 は，たとえばバックグラウンドをどら差し引くかと言つ た装置自体の特性によつておこることも考学られるから である.オージェ電子スペクトルの形から結合状態を議 論するためには, より一層の理論的, 実験的研究が必要 である・

$\dagger^{2}$ 乙の $\mathrm{Fe}-15.6 \% \mathrm{P}$ 合金（ $\mathrm{Fe}_{3} \mathrm{P}$ の組成に相当）は粉末鉄と赤りンを 混合反応させて作つた。

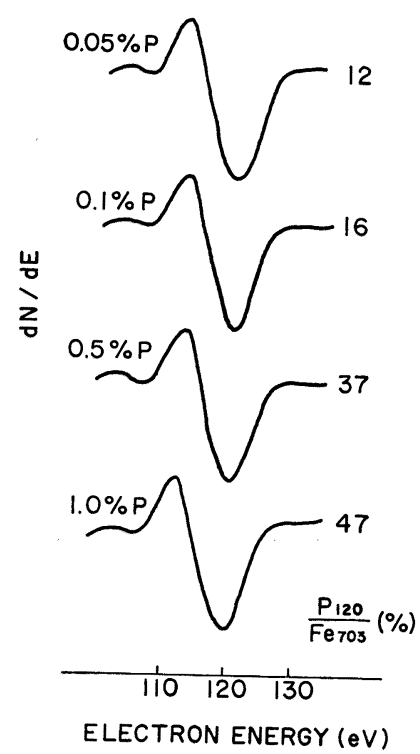

Fig. 6. AES of phosphorus segregated to grain boundaries in $\mathrm{Fe}-\mathrm{P}$ alloys with various $\mathrm{P}$ concentrations. Since fracture mode is not intergranular but cleavage in alloys with more than $1.7 \% \mathrm{P}$, their spectra are not shown.

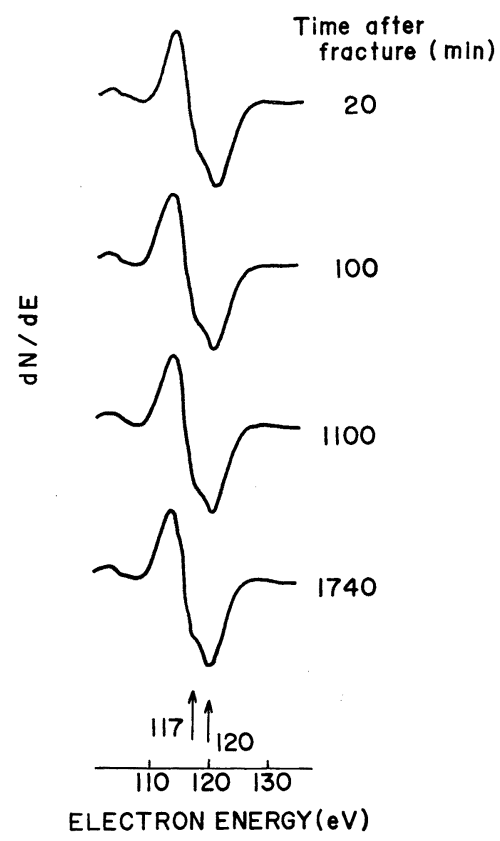

Fig. 7. AES of phosphorus segregated at grain boundaries in an $\mathrm{Fe}-1.0 \% \mathrm{P}$ alloy (modulation$1 \mathrm{eV})$. The shape of the curve does not change with time after fracture. 
Fig. 5 および Fig. 6 の結果では固溶したP の状態に ついての結論は得られなかつたが，この結果は粒界偏析 した $\mathrm{P}$ の定量分析に際して注意すべき点を示している. すなわち，Fig. 5 の結果から偏析した $\mathrm{P}$ の定量分析のた めの検量線を作ることはできないということである・通 常 AES 分析によつて定量分析する時には，スペクトル の微分曲線 $d N / d E(N$ は土ネルギーEのオージェ電子数 $)$ のピークからピークまでの距離(ピーク高さ $\left.I_{\mathrm{p}}\right)$ をとり, これを濃度既知の試料について求めて検量線を作り, 濃 度未知の試料からの結果と比較する. しかし， $I_{\mathrm{p}}$ の比較 で分析される原子の量一つまり $N(E)$ の積分値一の 比較ができるためには，縦軸のスケールを変えて $d N / d E$ 曲線を重视ることができなければならない，従来の AES 分析による定量分析においてはこの点に対する考慮がな されていない，Fe 中の $\mathrm{Cr}, \mathrm{Ni}, \mathrm{Mo}$ という合金元素 については，合金濃度と $I_{\mathrm{p}}$ が比例することを示して， $I_{\mathrm{p}}$ を用いることの妥当性を主張した研究はあるが14), 曲 線の形を検討した例はない, 本研究の結果は, 固溶した $\mathrm{P}$ の濃度とへき開面で測定した $I_{\mathrm{p}}$ の間にはほぼ直線関 係が成立するるのの，そのことだけではこの結果を外挿 して偏析した $\mathrm{P}$ の定量分析を行つてよいことにはならな

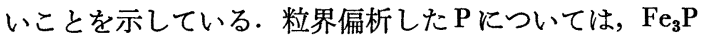
（粒界での濃度に換算して 25 at. \%)の $\mathrm{P}$ からの $I_{\mathrm{p}}$ と比 較して定量するか，あるいはPを約 $3 \mathrm{wt} . \%$ 以上固溶し た試料のへき開面からの $I_{\mathrm{p}}$ を用いなければならない。 低濃度の P を含む試料のへき開面からのスペクトルの $I_{\mathrm{p}}$ を標準にすると， $\mathrm{Fe}_{3} \mathrm{P}$ からのスペクトルの $I_{\mathrm{p}}$ を標 準にした場合よりる30\%くらい低く，P濃度を推定する ことになる. 他の元素を定量分析する場合にも固溶量と $I_{\mathrm{p}}$ との比例関係もさることながら, 厳密には常に $d N /$ $d E$ 曲線の形について検討することが必要である.

\section{4. 結論}

種々の量の $\mathrm{P}$ を含む Fe-P 合金について，残留ガスに よる破面污染の おこらない超高真空中で試験片を破断
し，XPS ならびに AES 分析を行つた.

粒界に偏析した $\mathrm{P}$ の化学結合状態は $\mathrm{Fe}_{3} \mathrm{P}$ 中の $\mathrm{P}$ のそ れと同じである.たがし，このことは $\mathrm{P}$ が粒界に $\mathrm{Fe}_{3} \mathrm{P}$ として析出していることを意味するものではない，Pは 粒界面から数原子層のごく薄い領域に偏析している. 化 学結合状態についてのこの結論は，Pによる鉄の粒界結 合力の低下に対する Losch のモデルを支持している.

素材電解鉄マイロンは東邦亜鉛株式会社から提供され たものであり，同社に対して深く謝意を表する.

\section{交献}

1) $K$. Abiko, $S$. Suzuki, and $H$. Kimura: Trans. JIM 23 (1982), p. 43

2) M. P. SeAH: Acta Metall., 28 (1980), p. 955

3 ) W. G. HARTweck: Scripta Metall., 15 (1981), p. 453

4 ) W. Losch: Acta Metall., 27 (1979), p. 1885

5) 小川孝好, 石田洋一：日本金属学会誌，43 (1979), p. 1048

6) R. P. Messmer and C. L. Briant: Acta Metall., 30 (1982), p. 457

7 ) C. L. Briant and R. P. Messmer: Phil. Mag., 42 (1980), p. 569

8 ) 例えば, $K$. Hirokawa, $F$. Honda, and $M$. OkU: J. Electron Spectrosc. Related Phenom., 6(1975), p. 333

9 ) $M$. Pelvin, $D . N$. Hendrickson, $J . M$. HollanDER, and W. L. Jolly: J. Phys. Chem., 74 (1970), p. 1116

10) $V . I$. Nefedov, $D$. Gati, $B . F$. Dzhurinski, $N$. $P$. Sergushin, and $Y a . V$. Salyn: $Z$ h Neorg. Khim., 20 (1975), p. 2307

11) $K$. Hirokawa and $M$. Oku: Talanta, 26 (1979), p. 855

$M$. Oku and $K$. Hirokawa: J. Appl. Phys., 50 (1979), p. 6303

12) $K$. Hirokawa, $S$. Suzuki, $K$. Abiko, $H$. Kimura, and $M$. OkU: J. Electron Spectrosc. Related Phenom., 24 (1981), p. 243

13) D. F. Stein, $W . C$. Johnson, and C. L. White: Grain Boundary Structure and Properties, ed. by $G$. $A$. Chadwick and $D . A$. Smith (1976), p. 301 [Academic Press]

14）小俣裕保，小川洋之：日本金属学会誌，42 (1978), p. 1200 